\title{
No Unnecessary Burden: Taxpayers and the Politics of Work, Family, and Welfare
}

\author{
Molly C. Michelmore (iD
}

The history of the Social Security Amendments of 1967 illuminates the contours of fiscal citizenship. This watershed law created both work requirements for Aid to Families with Dependent Children (AFDC) recipients and new policy instruments, including federal child support enforcement, to compel poor men to fulfill their financial obligations to their families. Welfare reformers claimed that such changes were necessary to protect the rights of taxpayers against the "criminal" predations of welfare recipients. These policy changes initiated in 1967 redefined poor women's non-work, as well as their sexual and reproductive decisions, as crimes against taxpayers. Welfare recipients contested this logic and the policies that flowed from it by insisting on the value of their own domestic labor and rejecting a narrow view of taxpaying citizenship. The resolution of these questions played a critical role in revising the American social contract.

In late August 1967, hundreds of welfare recipients "jammed the heavily guarded Senate Caucus Room" to stage a "mock hearing" against proposed changes to the Aid to Families with Dependent Children (AFDC) program. Organized by the National Welfare Rights Organization (NWRO), the "Mother's March on Washington" denounced the House-passed bill-which included work requirements, provisions to punish nonmarital childbirth, and new tools to track down "Runaway Poppas" for child support payments-as a "betrayal of the poor." Later that day, a crowd of 1,000 welfare activists marched from Capitol Hill to the U.S. Department of Health, Education, and Welfare (HEW) to protest the "tame HEW opposition" to the proposal. According to press reports, one speaker, Beulah Sanders, a New York activist and NWRO vice chair, told the crowd that their "money had paid for the Capitol and the group should 'go in there and tear it down if they [lawmakers] don't listen to you."' 1 The protests had little effect on Congress. Signed into law by President Lyndon B. Johnson on January 2, 1968, the Social Security Amendments of 1967 marked the first step toward a new national consensus on welfare reform: work requirements and incentives for poor mothers coupled with strategies intended to force poor men to fulfill their financial obligations to their families and to punish those who failed to do so. Congressional welfare reformers in both parties defended these changes as necessary to protect the rights of taxpayers against the predations of welfare recipients. These policy prescriptions_-as well as their rhetorical framing — shaped and justified welfare reform into the twenty-first century.

The outcome was hardly a foregone conclusion. Indeed, Congress's insistence on requiring that mothers-even mothers of young children-work for wages was a significant departure from past practice. U.S. welfare policy had long assumed, in theory if not in execution, that welfare policy should enable women to stay at home with their children without resorting to market labor. ${ }^{2}$

\footnotetext{
${ }^{1}$ Carol Honsa, "Welfare Bill Held 'Betrayal of Poor': Congressmen Denounced by 1000 Pickets," Washington Post, Aug. 29, 1967, A9.

${ }^{2}$ In truth, welfare had never provided poor mothers with sufficient resources to forgo waged work altogether, and most women combined market labor and welfare to make ends meet. For instance, see Joanne L. Goodwin, (c) The Author(s), 2021. Published by Cambridge University Press
} 
The New Deal-era Social Security Act-often referred to as the cornerstone of the U.S. welfare state-treated women not as workers, but as "dependents" of male workers and the caretakers of young children. ${ }^{3}$ The War on Poverty and Great Society likewise promised to use public resources to shore up the male-breadwinner family by providing jobs or job training for men and welfare grants designed to replace male wages to single-mother families. ${ }^{4}$

By the late 1960s, however, the consensus around that male-breadwinner family was falling apart. Women's labor force participation, which accelerated in the 1950s and 1960s despite the cultural celebration of female domesticity, gave rise to a new feminist sensibility focused, in part, on eliminating economic discrimination on the basis of sex. Such efforts included not only legal campaigns to open labor markets to women, but also political efforts to assert women's right to equal economic citizenship. As Alice Kessler-Harris has pointed out, by the 1960s, "tax breaks, benefits, and employment privileges tied to gender and marital status no longer signified fairness as readily as they once had." The collapse of this gendered consensus led to a renegotiation of the social contract, including the creation of different tax rates for married and unmarried tax filers, changes in the calculation of Social Security survivors' benefits, and the recognition of the principle of equal pay for equal work. ${ }^{6}$

These changes had significant consequences for welfare policy in the United States. As white middle-class women began to assert their right to make choices about work and family, other women, namely poor women of color, "replaced them in the foreground of public discussion and concern." At the same time, the collapse of the postwar economic boom, the backlash to the Black freedom movement, and the shattering of the New Deal coalition created political incentives for both the left and the right to advocate a politics dedicated to the protection of the taxpayer. These trends were evident in the discussions around welfare reform that began in 1967 and solidified as a broad consensus about the value of poor women's work and the legitimacy of taxpayers' claims to state protection. Ironically, liberal feminists' challenge to "dependency" on male wages as the natural state for women created space to redefine poor women's domestic labor as "non-work." The policy shifts begun in 1967 eventually enshrined this change in law, redefining poor women's "non-work," as well as their sexual and reproductive decisions, as a kind of fraud perpetrated against hardworking taxpayers.

\footnotetext{
“'Employable Mothers' and 'Suitable Work': A Re-Evaluation of Welfare and Wage-Earning for Women in the Twentieth-Century United States,” Journal of Social History 29, no. 2 (Winter 1995): 253-74.

${ }^{3}$ For more on the gendered history of U.S. welfare policy, see Linda Gordon, "The New Feminist Scholarship on the Welfare State," in Women, the State, and Welfare, ed. Linda Gordon (Madison, WI, 1990), 9-35. See also Mimi Abramovitz, Regulating the Lives of Women: Social Welfare Policy from Colonial Times to the Present, rev. ed. (Boston, 1996); Gwendolyn Mink, The Wages of Motherhood: Inequality in the Welfare State, 1917-1942 (Ithaca, NY, 1995); Barbara J. Nelson, "Women's Poverty and Women's Citizenship: Some Political Consequences of Economic Marginality," in Women and Poverty, eds. Barbara C. Gelpi, Nancy C. M. Hartsock, Clare C. Novak, and Myra H. Strober (Chicago, 1986), 209-31; Carole Pateman, "The Patriarchal Welfare State," in Democracy and the Welfare State, ed. Amy Gutmann (Princeton, NJ, 1988), 231-60; and Virginia Sapiro, "The Gender Basis of American Social Policy," in Women, the State, and Welfare, ed. Linda Gordon (Madison, WI, 1990), 36-54.

${ }^{4}$ See Robert O. Self, All in the Family: The Realignment of American Democracy Since the 1960s (New York, 2012).

${ }^{5}$ Alice Kessler-Harris, In Pursuit of Equity: Women, Men, and the Quest for Economic Citizenship in 20th Century America (New York, 2001), 5.

${ }^{6}$ For more on the relationship of the federal income tax code to marriage, see Molly Michelmore, "Creating the Marriage Penalty: Tax Politics, Gender, and Political Realignment in 1970s America," Journal of Women's History 30, no. 2 (Summer 2018): 136-60. For more on the political and policy history behind the Equal Pay Act of 1963, see Kessler-Harris, In Pursuit of Equity, ch. 5.

${ }^{7}$ Rickie Solinger, "Dependency and Choice: The Two Faces of Eve," in Unequal Sisters: A Multicultural Reader in U.S. Women's History, 3rd ed., eds. Vicki L. Ruiz and Ellen Carol DuBois (New York, 2000), 615.

${ }^{8}$ For a genealogy of the political use of the term "dependency," see Nancy Fraser and Linda Gordon, “'Dependency' Demystified: Inscriptions of Power in a Keyword of the Welfare State," Social Politics 1, no. 1 (Spring 1994): 4-31.
} 
These changes did not go uncontested. Welfare recipients and their allies challenged Congress's legal and moral authority to "force women out of the home." Insisting on the value of their own work as mothers, welfare recipients pushed back against lawmakers in both parties whose insistence that "the able-bodied will work for their keep" denigrated and erased their own work inside the home. ${ }^{10}$ Unlike previous generations of "maternalist" reformers, who had largely come out of the white, native-born middle class, welfare rights activists in the 1960s and 1970s were themselves poor women, and often poor women of color. ${ }^{11}$ Not surprisingly, these mothers' understanding of meaningful "work" differed not only from welfare's conservative critics, but also from that of an earlier generation of reformers, as well as that of many liberal feminists, by valuing both market labor and care work and linking both to essential citizenship rights. ${ }^{12}$

Just as welfare mothers embraced a more capacious definition of "work," they also contested the boundaries of "taxpaying citizenship" that had begun to harden by the late 1960s. Welfare activists deliberately rejected the idea that they were not taxpayers entitled to protection both by and from the state. Just as Sanders told the Mothers March that they had "paid for the Capitol," NWRO member Alice Nixon reminded the Senate Finance Committee that welfare recipients were taxpayers. "What do you mean we are not taxpayers?" she asked. "Every time we buy a can of beans we keep the bean farmer in business, or we buy a can of tomatoes we keep the steel people in business." ${ }^{\prime 3}$ Nixon and other welfare rights activists spoke directly from their own experiences as caregivers, wage earners, and consumers. By calling attention to sales as well as other direct and indirect taxes, Nixon pointed to a thicker-and more accurate-notion of taxpaying citizenship than one grounded solely on income tax liability.

The resolution of these contests over the economic and social value of women's domestic and market labor and the deference due to taxpayers played a critical role in revising the American social contract and the "hollowing out of obligations citizens could impose on the government." ${ }^{14}$ As Julilly Kohler-Hausmann has shown, these general trends, grounded in a cramped "contractual understanding of citizenship [helped] produce the trope of a nation divided between rights-bearing, taxpaying Americans and a racialized, denigrated underclass." ${ }^{\prime 15}$ Despite the successes of the welfare rights movement in organizing at both the grassroots and nationally and in wresting some administrative, policy, and legal concessions from welfare offices, state and national legislatures, and the courts, the sex, race, and class of welfare mothers ultimately circumscribed their claims to rights and protection. ${ }^{16}$

\footnotetext{
${ }^{9}$ George Wiley, qtd. in Honsa, "Welfare Bill Held 'Betrayal of Poor," A9.

${ }^{10}$ Ronald Reagan, qtd. in Annelise Orleck, Storming Caesars Palace: How Black Mothers Fought Their Own War on Poverty (Boston, 2005), 128.

${ }^{11}$ For a history of "maternalism" and its role in the construction of the U.S. welfare state, see Linda Gordon, Pitied but Not Entitled: Single Mothers and the History of Welfare, 1890-1935 (New York, 1994); Mink, The Wages of Motherhood; and Robyn Muncy, Creating a Female Dominion in American Reform, 1890-1935 (New York, 1991). For a comparative analysis of "maternalism" and the origin of welfare states in the United States and Europe, see essays in Seth Koven and Sonya Michel, eds., Mothers of a New World: Maternalist Politics and the Origins of Welfare States (New York, 1993).

${ }^{12}$ For more on the welfare rights movement, see Tamar W. Carroll, Mobilizing New York: AIDS, Antipoverty, and Feminist Activism (Chapel Hill, NC, 2015). See also Felicia Kornbluh, The Battle for Welfare Rights: Politics and Poverty in Modern America (Philadelphia, 2007).

${ }^{13}$ U.S. Congress, Senate, Committee on Finance, Social Security Amendments of 1967: Hearings (Part II), 90 Cong., 1st sess., Sept. 19, 1967, 1467.

${ }^{14}$ Felicia Kornbluh and Gwendolyn Mink, Ensuring Poverty: Welfare Reform in Feminist Perspective (Philadelphia, 2019), xv.

${ }^{15}$ Julilly Kohler-Hausmann, Getting Tough: Welfare and Imprisonment in 1970s America (Princeton, NJ, 2017), $6-7$.

${ }^{16}$ Kohler-Hausmann, Getting Tough, 16. For more on the legal campaign for welfare rights, see Elizabeth Bussiere, (Dis)entitling the Poor: The Warren Court, Welfare Rights, and the American Political Tradition
} 
The 1967 law initiated a fundamental reconfiguration of the relationship between work, welfare, and citizenship. Contrary to traditional accounts of the "right turn" in U.S. politics, or conservative and neoliberal rhetoric, this new social contract did not bring the "era of big government" to an end, nor did it necessarily devolve federal responsibility to the states. ${ }^{17}$ As Anna Marie Smith has pointed out, "From the 1970s onward, the federal government increasingly imposed new welfare initiatives upon the states that effectively restricted welfare eligibility, augmented federal oversight, and allowed the federal government to advance the project of rendering the poor mass into a policeable totality." 18 This moment thus represents not so much a retrenchment as a reconfiguration of relationship between state and citizen, which at once weakened poor families' claims on the state and promised new protections to politically privileged groups, including workers but especially taxpayers.

This history also calls attention to how liberal and even feminist approaches to welfare policy undermined poor mothers' citizenship. The effective criminalization of both "non-work" and "illegitimate" reproduction by poor women is a product of a liberal reform era that yoked the War on Poverty to the War on Crime. ${ }^{19}$ The collapse of the male-breadwinner consensus, in conjunction with racist devaluation of non-white women's claims to recognition and protection as mothers, allowed for the creation of what Eva Bertram has termed the "workfare state." Liberal feminists' embrace of the language of choice too often framed reproductive and economic decisions as "choices" freely made rather than responses to structural inequities. ${ }^{21}$ Ironically, second-wave feminism's pursuit of gender justice in the marketplace ultimately undermined poor women's ability to choose how best to combine their own care work and labor participation, and also assisted the implementation of harmful welfare policies.

The Social Security Amendments of 1967 represented Congress's first attempt to get control of welfare policy. ${ }^{22}$ Led by Arkansas Democrat chairman Wilbur D. Mills, the House Ways and Means Committee rewrote a Johnson administration proposal to liberalize AFDC and increase Social Security benefits. ${ }^{23}$ The new Ways and Means bill froze the level of federal money

(University Park, PA, 1997). See also Martha F. Davis, Brutal Need: Lawyers and the Welfare Rights Movement, 1960-1973 (New Haven, CT, 1993).

${ }^{17}$ In his 1996 State of the Union Address, President Bill Clinton declared the "era of big Government" to be over and pointed to decreases in the "welfare and food stamp rolls" as evidence of his administration's success. See William J. Clinton, "Address Before a Joint Session of the Congress on the State of the Union," by Gerhard Peters and John T. Woolley, The American Presidency Project online, https://www.presidency.ucsb.edu/node/ 223046 (accessed Mar. 13, 2021). For an analysis of "devolution," see Michael B. Katz, The Price of Citizenship: Redefining the American Welfare State (New York, 2001).

${ }^{18}$ Anna Marie Smith, Welfare Reform and Sexual Regulation (Cambridge, UK, 2007), 85.

${ }^{19}$ For a pathbreaking analysis of the Great Society roots of the "war on crime" and mass incarceration, see Elizabeth Hinton, From the War on Poverty to the War on Crime: The Making of Mass Incarceration in America (Cambridge, MA, 2016). Jennifer Mittelstadt's work on liberal welfare reform in the 1950s and 1960s, and the embrace of the "rehabilitative welfare state," has also shown the liberal roots of conservative welfare policy and political language. For more, see Jennifer Mittelstadt, From Welfare to Workfare: The Unintended Consequences of Liberal Reform, 1945-1965 (Chapel Hill, NC, 2005).

${ }^{20}$ Eva Bertram, The Workfare State: Public Assistance Politics from the New Deal to the New Democrats (Philadelphia, 2015).

${ }^{21}$ On the limits of a politics of choice, see Rickie Solinger, Beggars and Choosers: How the Politics of Choice Shapes Adoption, Abortion, and Welfare in the United States (New York, 2001).

${ }^{22}$ Earlier efforts at welfare reform, including the 1962 Public Welfare Amendments and the previous year's amendments to Title IV (ADC) of the Social Security Act, had been driven by the executive branch. The 1961 law allowed states to extend ADC benefits to unemployed fathers for the first time. The 1962 changes required states to provide "rehabilitative" services designed to move recipients off the welfare rolls and into the labor market. See Mittelstadt, From Welfare to Workfare, ch. 4.

${ }^{23}$ The White House had proposed to increase minimum benefit levels and to require states to adopt the optional Aid to Families with Dependent Children-Unemployed Parent program. In place of these modest liberalizations, the Ways and Means Committee froze the level of assistance available to children born out of wedlock and created a 
available to children born out of wedlock and imposed work requirements on welfare recipients. The Senate later added a proposal to collect support payments from what Chairman Long usually referred to as "Runaway Poppas." 24 Taken together, these changes aimed to punish nonmarital reproduction, to enforce participation in low-wage labor markets, and to relieve the "undue" burden welfare put on hardworking taxpayers. These proposals, which represented the culmination of previously disparate trends in welfare reform policy, were imperfectly implemented in the decades following the passage of the law. Nevertheless, they pointed toward the new welfare consensus that guided policy making into the next century. Lawmakers acted in 1967 to stem what was widely seen as a crisis in the U.S. welfare system. Over the course of the 1960s, the cost and size of AFDC had increased dramatically, owing in large part to the political mobilization of welfare recipients into welfare rights organizations (WROs) and to court decisions curtailing states' ability to prohibit otherwise eligible recipients from receiving public assistance. ${ }^{25}$ Between 1960 and 1974, the rolls swelled from 3.1 million to almost 11 million recipients. ${ }^{26}$ Costs rose correspondingly. Perhaps more important to its political fortunes, the program served increasing numbers of nonwhite women. By 1967, the AFDC caseload, which had once been 86 percent white, had become 46 percent nonwhite. ${ }^{27}$ Although Black Americans never made up the majority of the welfare caseload, they were overrepresented on the welfare rolls and, by the 1960s, dominated popular discourse about public assistance.

The racialization of welfare politics had as its flip side a politics conflating whiteness with taxpaying citizenship. ${ }^{28}$ At the state and local levels, civil rights opponents used the language

new "workfare" program. For more, see Molly C. Michelmore, Tax and Spend: The Welfare State, Tax Politics, and the Limits of American Liberalism (Philadelphia, 2012), ch. 4.

${ }^{24}$ For a summary of the bill, see U.S. Congress, Senate, Committee on Finance, HR 12080: Brief Summary of Major Provisions, 90 Cong., 1st sess., 1968, 60, 20. For background on and a description of the provision of the bill freezing AFDC payments for the children of unwed mothers, see Premilla Nadasen, Jennifer Mittelstadt, and Marissa Chappell, Welfare in the United States: A History with Documents, 1935-1996 (New York, 2009), 43-4. For background on the development of Senator Long's "Runaway Poppas" amendment to HR 12080, see Finance Committee, "Runaway Parents Location and Liability: Memorandum"; "Runaway Parents: Draft, 11/1/ 67"; “Amendment Not Yet Formally Introduced, 'Run-Away Poppa' (Sen. Long)"; "Explanation of How 'Run-Away Poppa' Amendment of Senator Long's Would Work,” Oct. 23, 1967; all in folder Runaway Poppas, box 35, Bill Files: HR 12080, National Archives and Records Administration, Senate Finance Committee. State and local governments had long been focused on collecting child support payments from absent fathers. The federal government gave some support to these efforts in 1950 when it required welfare officials to report any child applying for public assistance due to "desertion" to the appropriate law enforcement agency. This "notification of law enforcement officials," or "Noleo," provision combined social welfare provision with law enforcement and moved the states toward a more punitive ADC policy. However, Noleo did not impose any federal obligation to collect child support payments or prescribe punitive measures if a mother refused to cooperate in state paternity establishment and collection procedures.

${ }^{25}$ Welfare recipients began to organize at the grassroots in the late 1950s and early 1960s. According to Premilla Nadasen, most of these local groups first addressed practical problems facing welfare recipients. A Detroit group, for example, came together in a campaign to win clothing allowances from the welfare department, to obtain babysitting subsidies for women involved in Work Experience programs, and to convince the post office to put locks on apartment building mailboxes to protect welfare checks. Local groups came together in a National Welfare Rights Organization (NWRO) in 1967. Though the vast majority of NWRO members were women of color, the leadership of the new organization was dominated by men. For more, see Premilla Nadasen, "Expanding the Boundaries of the Women's Movement: Black Feminism and the Struggle for Welfare Rights," Feminist Studies 28, no. 2 (Summer 2002): 271-301.

${ }^{26}$ As Julilly Kohler-Hausmann notes, these increases were driven largely by the fact that states were "finally beginning to pay a great percentage of ... citizens the benefits to which they were entitled." During the early 1960s, only one-third of statutorily eligible citizens received AFDC benefits; by 1971, that percentage had almost tripled to 91 percent. See Kohler-Hausmann, Getting Tough, 134.

${ }^{27}$ Dorothy Roberts, Killing the Black Body: Race, Reproduction and the Meaning of Liberty (New York, 1999), 207.

${ }^{28}$ For more, see Camille Walsh, Racial Taxation: Schools, Segregation, and Taxpayer Citizenship, 1869-1973 (Chapel Hill, NC, 2018). 
of taxpayer rights to counter the claims of the Black freedom movements. This language insisted on the independence of implicitly white taxpayers by defining them against the alleged dependence of Black families reliant on public services. Critics of Brown v. Board of Education, and of the civil rights movement more generally, accused Black Americans of "living off the "fat of the land" "and "doing wonderfully well ... at the expense of the white people."29 "The Negro in Alabama," one white Alabamian wrote to Supreme Court justice Hugo Black in 1955, is "getting ten times more school tax money for their schools than they contribute." 30 "We are very much opposed," another complained, "to having our tax money used for government housing projects to be taken over by the Negroes who pay very little in taxes." 31 Lawmakers repeated and reinforced this racialized understanding of taxpaying citizenship and its dependent inverse. In 1959, Arkansas governor Orville Faubus, for example, complained that by "taxing the good people to pay for $[\mathrm{ADC}]$, we are putting a premium on illegitimacy never before known in the world." ${ }^{32}$ As both a means and a language of massive resistance, taxpayer politics at once justified the campaign to "reform" welfare and depended on it.

Two racialized "crises" in the early 1960s linked taxpayer politics directly to welfare reform. In 1960, Governor Jimmie Davis convinced the Louisiana legislature to enact a new law prohibiting any family from receiving ADC payments if the mother conceived a child out of wedlock, lived with a man, or if a welfare caseworker deemed her somehow "promiscuous." Introduced as part of a larger "segregation package" that aimed to roll back civil rights reforms and to punish activists, the state's "suitable home law" targeted Black women. Indeed, almost all of the families cut from ADC as a result of these changes were Black. ${ }^{33}$ That same year, Joseph Mitchell, the town manager of the small Hudson River town of Newburgh, New York, announced a thirteen-point plan to cull the city's welfare rolls of "chiselers" loafing by "state or federal edict." Mitchell was open about the racial politics behind the plan; such steps were necessary, he said, because of the recent influx of "southern migrants" to the area. ${ }^{34}$

The Newburgh and Louisiana crises together shifted the terms of debate around welfare to center on the behavior of women rather than the needs of children. ${ }^{35}$ The focus on single mothers' "immorality" depended on and fueled the emergence of a national taxpayer politics that explicitly set the interests of white taxpayers against those of implicitly nonwhite welfare recipients. After meeting with Mitchell in Washington, DC, Senator Barry Goldwater told the press he did not like seeing "his taxes paid for children born out of wedlock." 36

Continued growth in the welfare rolls, challenges to and the defense of the color line, and an increasingly uncertain economy propelled Congressional and public interest in welfare reform. The Work Incentives (WIN) program, created by the 1967 Social Security Amendments,

\footnotetext{
${ }^{29}$ Unsigned letter to Hugo Black, undated, folder: Correspondence, Public: Segregation II, box 328, Library of Congress, Hugo Black Papers [hereafter HBP].

${ }^{30}$ W. E. Walker to Hugo Black, January 27, 1955, folder: Public Correspondence Re Segregation, box 325, HBP.

${ }^{31}$ Mrs. Thelma Smith of Birmingham to President Eisenhower, undated, folder: Public Correspondence Re Segregation, box 325, HBP.

${ }^{32}$ Qtd. in Rickie Solinger, Wake Up Little Susie: Single Pregnancy and Race before Roe v. Wade (New York, 2000), 30.

${ }^{33}$ Andrew Pope, "Making Motherhood a Felony: African American Women's Welfare Rights Activism in New Orleans and the End of Suitable Home Laws, 1959-1962," The Journal of American History 105, no. 2 (Sept. 2018): 291-310, here 296. Louisiana was not the first to pass a suitable home law; Mississippi did so five years earlier. However, the Louisiana action drew national and international attention thanks to a "protest campaign" organized by poor, black mothers, which drew "attention from national media, celebrities, and civil rights organizations." See Pope, 292.

${ }^{34}$ Qtd. in "The Battle of Newburgh,” NBC White Paper, New York: NBC News, Jan. 28, 1961.

${ }^{35}$ Lisa Levenstein, "From Innocent Children to Unwanted Migrants and Unwed Moms: Two Chapters in the Public Discourse on Welfare in the United States, 1960-1961," Journal of Women's History 11, no. 4 (Winter 2000): 10-33.

36“Relief: Soapbox Derby," Newsweek, July 31, 1961, 27.
} 
provided one set of answers to this welfare "crisis." First, the program promised to provide the welfare poor with the "sense of dignity, self-worth, and confidence" that flowed from "being recognized as a wage-earning member of society." 37 Second, WIN offered states a way to "deal effectively with the critical problem of mounting welfare costs and the increasing financial dependency of many ... citizens." ${ }^{38}$ Although the new work program built on existing employment programs, it was the first policy aimed squarely at AFDC recipients-the vast majority of whom were women with children. ${ }^{39}$ The law coupled work requirements with other provisions to encourage and incentivize waged work. ${ }^{40}$ The new law, for example, allowed welfare recipients to keep some of their earned income without losing AFDC benefits. ${ }^{41}$ By moving poor women off the welfare rolls and onto a payroll, supporters suggested, WIN would transform tax-eaters into taxpayers. In the long run, both work requirements and work incentives moved mothers into the category of "employable" worker and weakened women's claims to welfare benefits on the basis of their motherhood.

These "sweeping ... carrot-and-stick measures," the Wall Street Journal reported at the time, aimed to "equip for work the able-bodied men, women, and out of school youngsters on the AFDC rolls-and then force them to take available jobs." ${ }^{2}$ Advocates, including Chairman Mills, argued that the new law would allow "people now on public assistance to become selfsustaining." ${ }^{3}$ Another Ways and Means Democrat defended the new law as necessary to "break the cycle that is making welfare a way of life for generations of families" and predicted that a "great many mothers as well as virtually all unemployed fathers ... can be trained for and placed in productive employment." ${ }^{44}$ The intent of the law was simple enough: "Get Tough." ${ }^{45}$ By the end of the 1960s, it had become commonplace for welfare's critics to insist that all "able-bodied" recipients-even the mothers of young children-participate in market labor. This politics built on a long tradition of distinguishing between the worthy and unworthy poor. The policy implications of this distinction, however, had often been tempered by at least a rhetorical interest in the social and moral value of women's domestic labor. By the end of the 1960s, however, the political power of "motherhood"-particularly the motherhood of single Black women-was less than certain. ${ }^{46}$ As one California woman wrote Justice Black in 1969, welfare should help for "people who are physically incapable of holding a job" and "not ... the freeloaders or women who feel it is easier to have a baby than to work." ${ }^{47}$ As

\footnotetext{
${ }^{37}$ U.S. Congress, Senate, Committee on Finance, Implementation of Amendments to Improve the Work Incentive Program, 92 Cong., 2nd sess., June 26, 1972, 26.

${ }^{38}$ New York Department of Social Services v. Dublino, 413 U.S. 405, here 409, 413 (1973).

${ }^{39}$ For a brief history of the Community Work and Training Program and the Work Experience and Training programs, see Bertram, The Workfare State, ch. 1.

${ }^{40}$ The work requirements were less than effective. According to one historian, the law failed to require most AFDC recipients to do "anything beyond registering" for the program. Women with children under the age of 16 were explicitly exempted from the law's work programs and a provision that anyone "whose participation ... would not be in the best interest of that program" further undermined the law's effectiveness. Four years later, hoping to close these "loopholes," Congress amended the program to require all AFDC recipients to register for work and training programs. R. Kent Weaver, Ending Welfare as We Know It (Washington, DC, 2000), 56.

${ }^{41}$ Before 1967, welfare recipients lost one dollar in welfare benefits for every dollar they earned in paid employment. The 1967 amendments attempted to create an incentive to work by allowing recipients to keep the first thirty dollars per month of earned income, without a corresponding welfare grant reduction, plus one-third of any earned income. See U.S. Congress, House, Ways and Means Committee, Social Security Amendments of 1967: Report, 90 Cong., 1st sess., 1967, 16.

${ }^{42}$ Wilbur D. Mills, qtd. in Norman C. Miller, “Putting a 'Carrot and Stick' in Welfare,” Wall Street Journal, Aug. $17,1967,12$.

${ }^{43}$ Ibid.

${ }^{44}$ Anonymous Democrat, qtd. in Miller, "Putting a 'Carrot and Stick' in Welfare," 12.

${ }^{45}$ Miller, "Putting a 'Carrot and Stick' in Welfare," 12.

${ }^{46}$ Kessler-Harris, In Pursuit of Equity, 5.

${ }^{47}$ Linda Pohl to Justice Hugo Black, May 7, 1969, folder: Shapiro v. Thompson, box 407, HBP.
} 
this letter suggests, attacks on welfare often joined welfare recipients' alleged refusal to work for wages to their uncontrolled sexual appetites by linking rising tax burdens to "welfare parasites" and their "sex binges." 48

The emerging critique of welfare that produced the 1967 Amendments fused two previously distinct categories of welfare fraud: one focused on able-bodied men who refused to work and a second targeted at the sexual behavior of women. In the late 1940s and early 1950s, the focus of many fraud investigations were men who abused the public trust by drawing state and local general relief payments they did not need or deserve. A long Saturday Evening Post story in 1949 on "relief chiselers," for example, drew special attention to three "relief career" families whose heads were "men with eight, nine, and ten children respectively, who claimed they could not work because of various physical reasons." The article also featured the case of the so-called "Welfare King" of Detroit, a white man named "John E. O'Connor" who was the "father of fourteen." 49 When women were targeted as "cheats" or "chiselers," their offenses tended to be sexual in nature. According to the Saturday Evening Post, "numerous women, who claimed to have been deserted by their husbands ... were living, at least a part of the time, with

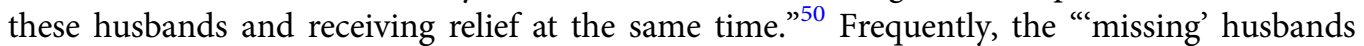
had good paying jobs." ${ }^{51}$ By the 1960s, unmarried mothers moved to center stage. A year after the "crises" in Louisiana and Newburgh, for example, Readers Digest introduced its readership to one "mother of seven who made a practice of sending her children out begging while she spent the ADC checks to feed steaks to her paramour" and another who "hit the $\$ 61,500$ jackpot by producing 14 illegitimate children." ${ }^{\text {2 }}$ Although the ADC program had been established to help "mothers who, widowed, or deserted, or divorced by missing husbands could not support their young children," the magazine lamented, in recent years it had come to foster "debauchery" and a "demoralizing dependency on government handouts." 53 Public outrage centered on women who had defrauded taxpayers by having children out of wedlock. In the same article, Readers Digest reported New Jersey lawmakers' incredulity that the "more illegitimate children a woman has, the more money she gets, not to mention ... free food and clothing." 54 That same month, Look reported that "ADC had done nothing to discourage the spawning of children out of wedlock" or check the "ballooning of the ADC program from \$133 million in 1940 to over \$1 billion today." 55

By the late 1960s, welfare reformers had fused these two forms of fraud-non-work and sexual misconduct-into what would later be labeled the "welfare queen." While sympathetic to the "best of our widows," Senate Finance Committee chairman Russell Long, for example, was forthright about regarding the mother "who goes to work and brings the family several hundred dollars a month income" as better than the one "who simply sits there and draws welfare checks and continues to increase the brood." ${ }^{56}$ During the same hearings, Long told Labor Secretary Willard Wirtz: "When people want the taxpayers to support" someone, "I would think they certainly ought to be willing to do something for it." ${ }^{\text {" }}$ The implications were

\footnotetext{
${ }^{48}$ Unsigned Letter to Justice Hugo Black, undated, folder: Goldberg v. Kelley, box 415, HBP.

${ }^{49}$ Rufus Jarman, “Detroit Cracks Down on Relief Chiselers," Saturday Evening Post, Dec. 10, $1949,19$.

${ }^{50}$ Ibid.

${ }^{51}$ Ibid.

${ }^{52}$ Charles Stevenson, "Children Without Fathers: The Shocking Truth About the Aid to Dependent Children Welfare Program,” Reader's Digest, Nov. 1961, 72-80, here 77-8. See also Josh Levin, The Queen: The Forgotten Life Behind an American Myth (New York, 2019), 41.

${ }^{53}$ Stevenson, "Children Without Fathers," 72.

${ }^{54}$ Ibid, 78 .

${ }^{55}$ Fletcher Knebel, “Welfare: Has It Become a Scandal?” Look 25, no. 23 (Nov. 7, 1961), 31-3, here 33.

${ }^{56}$ U.S. Congress, Senate, Committee on Finance, Social Security Amendments of 1967: Hearings (Part II), Aug. 29, 1967, 792-3.

${ }^{57}$ Ibid., 816.
} 
clear. By not working for wages, welfare mothers had failed to perform their civic duties as workers and as taxpayers and thus nullified their claims on the state.

This framing criminalized poor women's choice to prioritize care work over market labor and can be understood only in the context of broader shifts in the gendered organization of the American economy. In the early 1960s, both public policy and public opinion still allowed and expected employers to discriminate against married women and mothers in hiring and promotion decisions. ${ }^{58}$ Expert opinion concurred. The report issued by the President's Commission on the Status of Women (PCSW) in 1963 at once affirmed the principle of equal opportunity and assumed that most women with children would prioritize domestic over paid labor. ${ }^{59}$ Recognizing that "modern family life is demanding," the Commission recommended that "girls and women of all economic backgrounds ... receive education in respect to physical and mental health, child care and development, human relations within the family." Less than a decade later, however, the "comfortable belief that a woman's exclusive and rightful place is in the home" no longer described reality for many families. ${ }^{61}$ Nearly fifteen years later, that number had reached 50 percent. $^{62}$

As more and more mothers worked outside the home, traditional defenses of welfare spending became less compelling. Welfare programs had initially aimed to provide poor widows with enough money to forgo waged work and raise their children. ADC, created as part of the 1935 Social Security Act, federalized existing "mothers' pension" programs created by the states. While neither ADC nor its state-level predecessors ever provided mothers with sufficient resources to forgo waged work all together, the policies at least claimed an interest in enabling women's domestic labor by promising to replace lost male wages. When women's rising labor force participation precipitated a broad renegotiation of "women's appropriate roles and obligations" and challenged "popular understandings" of the value of women's domestic and market labor, such defenses lost much of their power. ${ }^{63}$ As Nancy Fraser and Linda Gordon have argued, "feminist and gay and lesbian liberation movements" helped to "change gender norms" and to "proliferate new family forms." These interventions made the "male breadwinner/female homemaker model less attractive to many" and empowered many women to pursue careers and to make choices that only a decade earlier might have been defined as "pathological." At the same time, however, feminist work around equal access to labor markets enabled and justified policies that cast poor women's alienation from the labor market as a dysfunctional and dangerous form of dependency. ${ }^{64}$

Feminist defenses of women's right to compete on a level playing field with men in the workforce also diminished the value of work done in the home. A 1968 National Organization for Women (NOW) Task Force Report, for example, concluded that the organization should actively pursue policies to reduce the "disproportionate involvement of women in the family at the expense of participation in work and community." ${ }^{65}$ Some went even further. The radical feminist Shulaminth Firestone, for example, saw a central aim of feminism as the

\footnotetext{
${ }^{58}$ For a fuller discussion, see Kessler-Harris, In Pursuit of Equity, 246-67.

${ }^{59}$ President's Commission on the Status of Women, American Women: Report (Washington, DC, 1963). The section on the educational needs of "mature women," for example, assumed that only after women raised children would they face "three decades of life after 40 when she will be relatively free to use her abilities and will wish to use them as constructively and interestingly as possible."

${ }^{60}$ Ibid., 16.

${ }^{61}$ Dominick v. Daniels, qtd. in Kessler-Harris, In Pursuit of Equity, 203.

${ }^{62}$ Kevin M. Kruse and Julian E. Zelizer, Fault Lines: A History of the United States Since 1974 (New York, 2019), 67.

${ }^{63}$ Kohler-Hausmann, Getting Tough, 126.

${ }^{64}$ Fraser and Gordon, "Dependency' Demystified," 15.

${ }^{65}$ National Organization for Women, Task Force on Poverty, Memorandum, 1968, box 31, Bentley Historical Library, University of Michigan, Ann Arbor, Martha Griffiths Papers [hereafter MG Papers].
} 
"freeing of women from the tyranny of reproduction." ${ }^{\prime 66}$ Black feminist Frances Beale concurred, calling full-time motherhood an "extremely sterile existence."67

In Congress, defenders of working women found an ally in Democratic Rep. Martha Griffiths of Michigan. Determined to end all forms of "economic discrimination against women," Griffiths hoped to use her appointment to the powerful House Ways and Means Committee and to the Joint Economic Committee to show how tax and spending policy disadvantaged working women. "The truth is," she wrote a constituent in 1973, "the working wife is paying for many of the improvements being made in social security [sic] today because she herself is not being treated fairly." 68

Like many of her male colleagues, Griffiths saw the larger welfare "problem" in terms of the "non-work" of the able-bodied poor and of family break-up and out-of-wedlock births. Only by helping "people get the educations and skills necessary to find and hold jobs" could government "reduce our welfare rolls." 69 However, where many of her male counterparts shied away from explicitly endorsing waged work by mothers with young children, Griffiths defended such work as the only way to address family poverty. As early as 1966, Griffiths argued that the "expansion of employment opportunity for women is surely one of the most effective and longlasting ways to reduce welfare payments and increase economic and social well-being." 70

Griffiths and others defended work incentives and requirements for poor mothers by invoking the existing division between taxpayer and tax-eater. By "giving mothers and children ... an opportunity to develop skills and improve the lives of their families," work training programs and requirements would allow women to become independent taxpayers. This politics pried open the benefits of taxpaying citizenship-a civic status long associated with men-to wage-earning women, but did so at the expense of their non-wage-earning counterparts. ${ }^{71}$ One critical problem with welfare, Griffiths insisted, was that it took from "women in this country with children under 6 who are in the middle class who are working and who are paying taxes." 72 Such taxes, she had written a constituent earlier, were then used to subsidize the motherhood of the "girl" with a "400-word vocabulary" who "becomes pregnant at 14 or 15."73 Drawing on hoary racial stereotypes about uncontrolled Black sexuality, Griffiths's defense of working women's economic citizenship depended on undermining the claims of welfare recipients and erasing the economic and social value of their domestic labor. ${ }^{74}$ By the end of the 1960s, other welfare reformers had embraced Griffiths's view that poor women should be forced into the labor market to protect other women's pocketbooks. Finance Committee Chairman Louisiana Democrat Russell B. Long, who had once told a group of welfare activists

\footnotetext{
${ }^{66}$ Shulamith Firestone, qtd. in Nadasen, "Expanding the Boundaries of the Women's Movement," 278.

${ }^{67}$ Frances Beale, qtd, in Nadasen, "Expanding the Boundaries of the Women's Movement," 278.

${ }^{68}$ Martha Griffiths to Mrs. Frank Wilcox, Aug. 1973, box 50, MG Papers.

${ }^{69}$ Martha Griffiths to Mr. and Mrs. Anthony Trumpka, June 9, 1969, box 39, MG Papers.

${ }^{70}$ Martha Griffiths to Mr. Harry Savage, Dec. 19, 1966, box 26, MG Papers. This position did not endear Griffiths to welfare mothers. When some began to float the Michigan Representative's name as a possible Supreme Court nominee, activist Beulah Sanders protested that Griffiths had been "terrible on welfare issues ... having advocated some of the worst forced work provisions" in Congress. Qtd. in Self, All in the Family, 123.

${ }^{71}$ For more on the gendered history of taxation, see Linda K. Kerber, No Constitutional Right to Be Ladies: Women and the Obligations of Citizenship (New York, 1998); and Edward J. McCaffery, Taxing Women: How the Marriage Penalty Affects Your Taxes (Chicago, 1997).

${ }^{72}$ U.S. Congress, Joint Economic Committee, Subcommittee on Fiscal Policy, Problems in the Administration of Public Welfare: Hearings, Part 1, 92 Cong., 2nd sess., Apr. 12, 1972, 205.

${ }^{73}$ Martha Griffiths to Ilse Nusbaum, Nov. 2, 1967, box 29, MG Papers.

${ }^{74}$ This is not surprising given the racial politics of welfare reform, and also Griffiths's own history with these issues. In 1964, Griffiths had helped to amend the Civil Rights Act 1964 to include "sex" in the landmark law's list of protected categories on the grounds that without amendment the law would give "colored women greater employment rights than white women." Griffiths later called the inclusion of the sex clause a "glorious victory" and wrote that she would be "be further darned if [she was] going to sit there while white women come in last at the hiring gate." Qtd. in Emily George, Martha W. Griffiths (Washington, DC, 1982), 152-3.
} 
that if they had "time to impede the work of Congress," they had time to "pick up some beer cans," likewise invoked the sacrifices of working women to justify efforts to get tough. "Does it seem fair to you," he asked, "for those mothers to work in my office ... to pay taxes to support welfare mothers who don't feel like working?"75

This was not, of course, the only way of understanding women's productive and reproductive labor and its relation to systematic sex discrimination. Welfare mothers, for example, explained how women's citizenship and autonomy might be recognized and supported. ${ }^{76}$ Many women first joined the welfare rights movement to protect their rights as mothers and to advocate for their families. ${ }^{77}$ Welfare rights activists embraced a vision of citizenship that insisted on their rights to full participation "in the economic, legal, and governmental institutions that shaped people's lives." ${ }^{78}$ Such women were understandably skeptical about "the arguments of white, middle-class feminists who thought paid work would make them free." 79 As Johnnie Tillmon reminded the readers of $M s$. magazine, "Up until now we've been raised to expect to work, all our lives, for nothing." Welfare mothers, Tillmon wrote, counted "less" as human beings. They were the "worst educated, the least skilled, the lowest paid people" who nevertheless had "to be almost entirely responsible" for their children. ${ }^{80}$ While "a lot of middle-class women [might see] women's liberation [as] a matter of concern, [it was] a matter of survival [for] women on welfare." ${ }^{81}$ The next year, Tillmon reprised this argument in front of Congress. Nonpoor women, she reminded the Joint Economic Committee, were neither required nor expected to work for wages: "If you're a society lady from Scarsdale, and you spend all your time sitting on your prosperity paring your nails, well, that's ok. Women aren't supposed to work. They're supposed to be married." ${ }^{2}$ American society and public policy, Tillmon and others pointed out, treated poor womenand especially poor women of color-differently. As one Ohio welfare recipient asked pointedly: "Jackie Kennedy gets a government check. Is anyone making her go to work?"

The NWRO officially opposed the Work Incentive Program-often referring to it as WIP (pronounced "whip") or "the slave labor program." Poorly paid, low-status market labor, these women recognized, would not provide material well-being, nor would it underwrite their own citizenship claims. Where congressional welfare reformers and their allies held out waged labor as the key to "independence," many welfare mothers countered that compulsory programs would make them a "slave forever more." ${ }^{84}$ Irene Gibbs, a New York City activist, for example, rejected a vision of welfare reform that prescribed waged work as the solution for women's poverty. ${ }^{85}$ During a demonstration at the Capitol protesting the 1967 Social Security Amendments, Gibbs declared proudly, "We let everybody know that we won't be

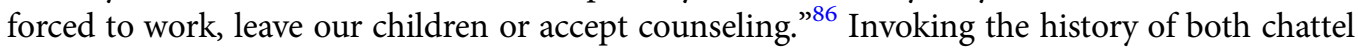
slavery and Jim Crow economic exploitation, welfare mothers insisted on their own capacity to make good choices about how to provide and care for their own families. Juliet Greenlaw, for example, told the 1968 Democratic Party Platform Committee, "We think the real reason for this bill is to force black people to take the maid and handyman jobs that no one else wants

\footnotetext{
${ }^{75}$ Sen. Russell Long, qtd. in Kessler Harris, In Pursuit of Equity, 273.

${ }^{76}$ Orleck, Storming Caesars Palace, 6.

${ }^{77}$ Nadasen, "Expanding the Boundaries of the Women's Movement," 278.

${ }^{78}$ Kornbluh, The Battle for Welfare Rights, 10.

${ }^{79}$ Ibid, 96.

${ }^{80}$ Johnnie Tillmon, “Welfare Is a Women's Issue,” Ms. Magazine, Spring 1972, 111.

${ }^{81}$ Ibid.

${ }^{82}$ U.S. Congress, Joint Economic Committee, Subcommittee on Fiscal Policy, The Economic Problems of Women: Hearings, Part 2, 93 Cong. 1st sess., July 24-26, and 30, 1973, 392.

${ }^{83}$ Qtd. in Nadasen, "Expanding the Boundaries of the Women's Movement," 284.

${ }^{84}$ Nancy Gooding, qtd. in Kornbluh, The Battle for Welfare Rights, 89.

${ }^{85}$ Qtd. in Kornbluh, The Battle for Welfare Rights, 88.

${ }^{86}$ Ibid., 102.
} 
to do and that don't pay enough to support our family. We have our own kitchen floors to scrub and our own children to look after!"87

Nevertheless many poor women saw waged work as one way for poor families to not only make ends meet, but, in Tillmon's memorable turn of phrase, to gain independence from both " $a$ man" and "the man." 88 Although the NWRO opposed WIN because it forced women to "take training [even] if it is not meaningful," many welfare rights activists welcomed federal jobs programs if they were truly optional and opened up pathways to economic citizenship. Although Tillmon deemed WIN "a waste of money and a waste of time," she nevertheless expressed support for voluntary work-training and -placement programs that would move women into the kind of jobs that would allow them to support their families. ${ }^{89}$ "A woman," Tillmon wrote in 1973, "should be able to choose whether to work outside her home or in it, to choose whether she wants to care for her own children all the time or part time."90 Beulah Sanders likewise urged lawmakers to "come up with the training program and the jobs" to get "us off the welfare rolls." ${ }^{91}$ Lily Mae Robinson, another New York City activist, "dreamed of a better Welfare system for all those who need it, for jobs for those of us who can work, for decent housing, and for the best education we can give our children." 92 Noted one New York activist, what was needed was "some jobs, man, some meaningful jobs, places to put our children." 93

At the same time as they demanded access to labor markets, welfare mothers also insisted on the value of their work in the home. NWRO slogans, including "MOTHER POWER," "VIVA MAMA!," and "REVOLUCION DE LAS MADRES!" all spoke to the centrality of motherhood in the politics of the welfare rights movement. ${ }^{94}$ As one welfare mother pointed out, "We work hard. A lot of people think that raising kids is not a job. But if you gonna raise three or four kids, you gotta keep the place clean. You got to wash. You got to cook. Believe me, that's a job any way you look at it." Wesley later recalled, "Give my kids to someone else to raise? Why would I do that? How could I do that?" Demands that Congress create a "subsidy for mothers" resembled early-twentieth-century maternalist demands for "mothers' pensions." Unlike that generation of social welfare reformers, however, WRO members, speaking from their own lived experiences, insisted on the economic and social value of both caregiving and market labor. ${ }^{97}$ Testifying before the Finance Committee in 1967, Sanders asked committee members to trust mothers to "know best what we want for our children because we had them." 98 For these women, public policies-including a "guaranteed annual income"-that recognized and compensated the parenting "work that is not now paid for by society" should be at the core of any social contract. ${ }^{99}$

\footnotetext{
${ }^{87}$ Ibid., $106-7$.

${ }^{88}$ Tillmon, "Welfare Is a Women's Issue," 111.

${ }^{89}$ Subcommittee on Fiscal Policy, The Economic Problems of Women, 372.

${ }^{90}$ Tillmon, "Welfare Is a Women's Issue," 115.

${ }^{91}$ Beulah Sanders interview by Nick Kotz and Mary Lynn Kotz, 1974, 12-3, 26, Nick Kotz Papers, Wisconsin Historical Society, Madison, WI, qtd. in Kornbluh, The Battle for Welfare Rights, 98.

${ }^{92}$ Qtd. in Kornbluh, The Battle for Welfare Rights, 38.

${ }^{93}$ Richard Rogin, "Now It's Welfare Lib," New York Times, Sept. 27, 1970, SM 16.

${ }^{94}$ Ibid.

${ }^{95}$ Rosie Seals, qtd. in Orleck, Storming Caesars Palace, 101. Seals was founding president of the Clark County Welfare Rights Organization.

${ }^{96}$ Qtd. in Orleck, Storming Caesars Palace, 84.

${ }^{97}$ Lillian Baines, "Why Not a Subsidy for Mothers," Welfare Fighter 1, no. 19 (1970).

${ }^{98}$ Committee on Finance, Social Security Amendments of 1967: Hearings (Part II), Sept. 19, 1967, 1465.

${ }^{99}$ Cassie B. Downer, "Guaranteed Adequate Income Now," in Welfare Mothers Speak Out: We Ain't Gonna Shuffle Anymore, eds. Thomas Howard Tarantino and Reverend Dismas Becker (New York, 1972), 132-6, here 135-6. See also Nadasen, "Expanding the Boundaries of the Women's Movement," 279. Public recognition of
} 
Work incentives and requirements did little to help poor women and their families. Many welfare mothers wanted a "decent job that's making something" so they could pay "rent, light and gas, phone bill, all the other goods" and "feed the kids." ${ }^{100}$ In practice, however, WIN relegated poor women to poorly paid jobs that offered few opportunities for advancement and did little to resolve the tension between women's domestic and market labor. ${ }^{101}$ To make matters worse, the program continued to prioritize male employment. As one Nevada mother later recalled, "Every time I went out for a WIN job, they would tell me I had too many kids. I wanted to work, but they would always say 'no."'102 Indeed, between 1968 and 1972, only 24,000 women were placed in WIN jobs. More than 80 percent of welfare mothers screened for the program were rejected as "inappropriate" for training - a designation widely understood to mean they had too many children. ${ }^{103}$ Even as public policy turned to work as an antidote to dependency, women's work was undervalued and deemed secondary to male labor. Welfare rights activists recognized this fact. "If I were president," wrote Tillmon in 1973, "I would solve this so-called welfare crisis in a minute and go a long way toward liberating every woman. I'd just issue a proclamation that women's work is real work." ${ }^{104}$

The Social Security Amendments of 1967 failed to move many women into paid employment, to promote their independence, to strengthen families, or even to save money. What the law did do was to lay the groundwork for a new direction on welfare reform-one focused on requiring all welfare "dependents" to work, regulating poor women's sexual behavior, and legitimating taxpayers' demands for state protection against the criminal predations of tax "chiselers" on the welfare rolls. It defined and strengthened the claims of taxpayer citizens not to be free of the state, but rather to claim its protection as a matter of right. Over the next decade, as economic growth slowed and then slipped into recession, and as inflation and unemployment ticked upward, the salience of taxpayer politics and its relationship to the gendered and racial politics of welfare reform only increased.

In 1971, Finance Chairman Russell Long took to the Senate Floor to talk about the "welfare mess." Focusing on the behavior of welfare recipients and the cost of that behavior to the public treasury, Long defined the failure of welfare mothers to work for wages, and of welfare fathers to support their children, as fraud perpetrated against hardworking taxpayers. To Long, it was "brutally unfair" to require "American taxpayers [who] are living up to their own responsibilities, supporting their own children ... to also support the children of the deadbeats who abandon them to welfare." 105 The Louisiana legislator was hardly alone in focusing on how welfare harmed supposedly innocent taxpayers. In 1973, newly elected Georgia Democratic Senator

the economic contribution of women's unpaid domestic labor would have benefited nonpoor women as well by providing married and unmarried women with routes to economic citizenship independent of their relationships to a wage-earning man. The so-called homemakers' movement later advocated such policies as changes to the Social Security system, revisions to divorce laws to provide homemakers with accident and health insurance after the divorce, unemployment insurance for homemakers, and adjustments in property law to compensate women for work done in the home. For more, see Lisa Levenstein, “Don't Agonize, Organize!': The Displaced Homemakers Campaign and the Contested Goals of Postwar Feminism," Journal of American History 100, no. 4 (Mar. 2014): 1114-38.

${ }^{100}$ Rogin, "Now It's Welfare Lib," SM 16.

${ }^{101}$ Affordable, federally subsidized child care might have done a great deal to resolve this tension. However, Nixon's veto of the Comprehensive Child Development Act in 1971 foreclosed this possibility. For more on the politics of the CCDA and its veto, see Self, All in the Family, 126-31.

${ }^{102}$ Qtd. in Orleck, Storming Caesars Palace, 129.

${ }^{103}$ Mary Wesley, qtd. in Orleck, Storming Caesars Palace, 129.

${ }^{104}$ Tillmon, "Welfare Is a Women's Issue," 116.

${ }^{105}$ U.S. Congress, Senate, Committee on Finance, The Welfare Mess: A Scandal of Illegitimacy and Desertion, Address of Hon. Russell B. Long, Chairman, Committee on Finance, and Supporting Material, 92 Cong., 1st sess., Dec. 14, 1971, 4. 
Sam Nunn, who had made child support enforcement a key issue in his election campaign, claimed that if only half of AFDC fathers started making \$50 monthly payments, U.S. taxpayers could save "more than half a billion dollars annually in support payments." ${ }^{06}$ Republican Senator Pete Domenici of New Mexico joined his Democratic colleagues in defending taxpayers' interests. "If more support money [were] obtained from the deserting parent," Domenici suggested, "fewer taxpayer dollars [would have to] be spent on the program for aid to families with dependent children."107

Legislators' willingness to sacrifice the rights and well-being of the dependent poor at once signaled and helped to produce and amplify the taxpayer politics of the late 1960s and early 1970s. As a 1970 memo written by the Chief of Staff to California Governor Ronald Reagan noted, welfare reform policy should "place heavy emphasis on the tax-payer as opposed to the tax-taker; on the truly needy as opposed to the lazy unemployable." 108 The rising salience of tax politics was one consequence of the collapse of the New Deal Order. The splintering of the Democratic coalition that dominated national politics for more than three decades led both the left and right to seek out ways to build a new electoral majority. Tax politics proved central to these efforts. While it looked at first like the left might rebuild a broad coalition by focusing public ire on "tax millionaires" who had "rigged" the tax code in their favor, the right ultimately claimed taxpayer politics as its own by tying the rising tax burdens borne by "ordinary" taxpayers to illegitimate welfare spending. ${ }^{109}$ This political strategy imagined a zero-sum competition between the property rights of implicitly white taxpayers and the economic needs of nonwhite tax eaters. ${ }^{110}$ Although the language of taxpayers' rights usually avoided explicit references to race, the right's capture of tax politics nevertheless depended on the era's racial politics. $^{111}$

Concern about welfare "loafers" cheating taxpayers was hardly new, of course. In the late 1940s, for example, the press had attacked the "cheats, bums, prostitutes, irresponsible parents, and well-heeled sons and daughters of the aged" who used tax monies for "whisky, marijuana and tropical fish." 112 In 1948, the New York City press reported almost gleefully on the so-called "Lady in Mink" who had bilked city taxpayers out of tens of thousands of dollars. ${ }^{113}$ But the unsettled economy of the 1970s, with its confounding combination of spiraling inflation, mounting unemployment, and stagnant growth, as well as the broader backlash against the Black freedom movements, made tax policy and politics even more salient. As one Californian wrote to Reagan in 1971, the "oppressed, depressed, suppressed, over-taxed, working taxpayer" needed "immediate action" to reverse the "staggering increase" in tax burdens

\footnotetext{
${ }^{106}$ Congressional Record, 93 Cong., 1st sess., June 27, 1973, 21712.

${ }^{107}$ Congressional Record, 93 Cong., 1st sess., Dec. 1, 1973, 39055.

${ }^{108}$ Qtd. in Kohler-Hausmann, Getting Tough, 144.

${ }^{109}$ For more, see Molly C. Michelmore, “What Have You Done for Me Lately?': The Welfare State, Tax Politics, and the Search for a New Majority, 1968-1980," Journal of Policy History 24, no. 4 (Oct. 2012): 709-40.

${ }^{110}$ In October 1969, Newsweek published a long article on the "Troubled American." This "special report on the white majority" found that the "Middle American," out of "perversity or ignorance," was convinced that "Negroes actually have a better chance to get ahead than he does and that any troubles blacks suffer are probably their own fault." A poll of white voters included in that same article found that more white Americans believed that "Negroes today have a better chance ... than people like yourself" to get a good job, to get decent housing, to get a "good education for their children," or to "get financial help from the government when they're out of work" than believed that Black Americans were discriminated against in labor and housing markets, in education, and in government welfare policy. See "The Troubled American: A Special Report on the White Majority," Newsweek, Oct. 6, 1969, 29-78, here 30, 45. For an analysis of “dog whistle” politics, see Ian Haney López, Dog Whistle Politics: How Coded Racial Appeals Have Reinvented Racism and Wrecked the Middle Class (Oxford, UK, 2014).

${ }^{111}$ For more, see Michelmore, "What Have You Done for Me Lately?"

${ }^{112}$ Jarman, "Detroit Cracks Down on Relief Chiselers," 122.

${ }^{113}$ The New York Times ran a three-column headline blasting the "Lady in Mink" in October 1947. See "Woman in Mink with \$60,000 Lived on Relief in a Hotel, Inquiry by State Discloses,” New York Times, Oct. 30, $1947,1$.
} 
due to "increased welfare payment." 114 Asked one woman of Justice Black, "Why should the honest, upright citizen Be continually raised taxes [sic] to meet the demands of able-bodied people for FREE grub, housing, medical care, etc.?"115 As AFL-CIO chief George Meany noted in the lead-up to the 1972 election, "Our guy thinks he's paying taxes so that somebody else can get welfare." 116

Such language obscured the racial assumptions that gave tax politics its power. Camille Walsh has shown how the status of the "taxpayer citizen" is deeply rooted in "historical elisions between 'taxpayer,' 'citizen,' and 'white." Such elisions have long helped to "justify and alibi racial inequality." 117 By the late 1960s and early 1970s, as the explicitly racist language and arguments that had once been mobilized to defend white supremacy lost currency and power in national politics, defenders turned to the language of taxpayer rights and class privilege to protect the existing racial hierarchy. "I am not against integration," wrote one Florida woman in 1970. "But," she added, African Americans should be "willing to work for it" and to "pay their fair share of the tax that is required to furnish schools to improve themselves." Another white couple complained that they had been "discriminated against" when they were told to "pay more taxes and run the risks of busing our children across town." 119 Wrote another, "We bought our home because of the location of the school, and now my eleven year old daughter has been reassigned to a formerly all Negro school seven miles from our home." ${ }^{\prime 20}$ Indeed, despite protestations to the contrary, such claims provide clear evidence of a deeply racialized politics that took the whiteness of taxpayers for granted.

At the same time that political discourse was being rearranged to insist that taxpayers be protected from the supposed predations of the liberal state, that same discourse also justified more intrusive interventions into the lives of the poor. Child support enforcement requirements, for example, promised to make fathers, rather than taxpayers, act as the "principal source of support" for dependent children. ${ }^{121}$ In this case, however, acting on behalf of taxpayer interests both jeopardized poor families' material well-being and required poor women give up freedom in a way that would never "be tolerated by middle-class women." ${ }^{122}$ The Child Support Enforcement Act of 1975, which "fixed" loopholes in the "Runaway Poppas" provision of the 1967 law, required all AFDC mothers to assign their family support rights to the state government as a condition of continued assistance and to assist the state in identifying and obtaining support from the fathers of their nonmarital children. ${ }^{123}$ These support orders then became a debt owed by the father to the state; any funds collected in excess of the amount of support a

\footnotetext{
${ }^{114}$ Qtd. in Kohler-Hausmann, Getting Tough, 148.

${ }^{115}$ Letter from Mrs. Ethel Krancer to Justice Black, undated, folder: Dandridge v. Williams, box 415, HBP.

${ }^{116}$ George Meany, Statement, Oct. 25, 1972, folder: October 1972, box 2, White House Special Files, Staff Member Office Files, Patrick Buchanan, Nixon Presidential Materials Project (NPMP), National Archives II, College Park, MD [hereafter NPMP]. The NPMP was relocated to the Nixon Presidential Library in Yorba Linda, CA, in 2010, after Congress amended the 1974 Presidential Materials and Recordings Preservation Act, which had required that all of Nixon's records remain within 50 miles of Washington, DC.

${ }^{117}$ Walsh, Racial Taxation, 2.

${ }^{118}$ Letter from Mrs. Jane McKinney to Hugo Black, Jan. 10, 1970, folder: Busing Mail, Florida and Georgia II, box 421 , HBP.

${ }^{119}$ Letter from Katherine and J. L. Raker to Hugo Black, Jan. 25, 1970, folder: Busing North and South Carolina I, box 422 , HBP.

${ }^{120}$ Letter from a mother in Greenville, S.C. to Hugo Black, Feb. 17, 1970, file: Busing North and South Carolina I, box 422, HBP.

${ }^{121}$ Congressional Record, 93 Cong., 1st sess., June 27, 1973, 21709. For more on the politics and history of what Anna Marie Smith has called "paternafare," see Smith, Welfare Reform and Sexual Regulation, especially chs. 1, 4, and 5 .

${ }^{122}$ Smith, Welfare Reform and Sexual Regulation, 100-1.

${ }^{123}$ An Act to Amend the Social Security Act to Establish a Consolidated Program of Federal Financial Assistance to Encourage Provision of Services by the States, Pub. Law 93-647, 88 Stat. 2337 (1975).
} 
woman was entitled to keep plus the monthly debt due to the state were returned to the state treasury in "reimbursement for any past assistance payments."

By targeting the so-called failure of the dependent poor to work for wages, work requirements undermined dependent mothers' claims for state protection and legitimized taxpayers as a rights-bearing group deserving of protection. In 1972, for example, Republican Governors Nelson Rockefeller and Ronald Reagan-hardly ideological soulmates-were both dispatched by the Nixon campaign to attack Democratic candidate George McGovern's "demogrant" proposal. According to the GOP talking points, the "McGovernite [guaranteed annual income] program" had "no work requirement" and would "embitter those who had to pay against those to whom they are paying." ${ }^{125}$ Nixon press aide Pat Buchanan made a similar argument a year earlier when he urged the administration to abandon its proposed Family Assistance Plan to take a "hardline on welfare" and "force Democrats to choose between the working class outraged by the excesses of the program and the welfare class." 126

Democrats joined their GOP colleagues in distinguishing between taxpayers and tax consumers, privileging the interests of the former group over the needs and rights of the latter. Griffiths, for example, encouraged her colleagues to "look at it for a minute" from the standpoint of the "taxpayer [who] is working." 127 According to the Michigan representative, welfare mothers' supposed refusal to work was nothing less than a million-dollar "theft" from the "taxpayers of the city and this county and the Federal Government and the State." 128 By defending work requirements in terms of the taxpayer dollars saved, this kind of welfare reform implied a direct link between welfare "fraud" and rising tax burdens, at the same time as it erased the economic and social value of poor women's care work. Punitive and coercive welfare reform legitimated taxpayers' claims to state protection by defining those claims against allegedly pathological and criminal behavior of welfare recipients. As activist Johnnie Tillmon wrote in 1972, welfare policy and practice required mothers to "give up control" of their bodies, to forgo sex, and to "agree to get ... [their] tubes tied ... just to avoid being cut off welfare."

Child support collection as a welfare reform strategy aptly illustrates this relationship. Federal Child Support Enforcement laws required poor women to trade basic rights to privacy and association in return for a grant from the state. Notably, liberal feminists played a key role in making the issue a federal priority. In 1971, researchers for the Rand Corporation published a report entitled "Non-Support of Legitimate Children by Affluent Fathers as a Cause of Poverty and Welfare Dependence." The study, which focused on well-off fathers, among them physicians and attorneys who had failed to pay court-ordered support, concluded that "fathers' non-support" had produced what the authors referred to as "middle-class poverty." 130 The report caught the attention of Congress. Nunn, for example, cited it in support of stepped-up child support enforcement measures. Griffiths likewise acknowledged the report's findings. Support amounts, she told her House colleagues, "were clearly not related to absent parents' incomes." Until we "clamp down on fathers who can contribute to their children's support ... we shall have great difficulty helping needy fathers who cannot contribute and needy fathers who do contribute." ${ }^{31}$ Griffiths's

\footnotetext{
${ }^{124}$ Ibid., 2356.

${ }^{125}$ Unsigned Memorandum to Governor Rockefeller and Governor Reagan, Aug. 18, 1972, box 2, White House Special Files, Staff Member Office Files, Patrick Buchanan, NPMP.

${ }^{126}$ Patrick Buchannan to H.R. Haldeman and The Attorney General, "Memo: Dividing the Democrats," Oct. 5, 1971, box 1, White House Special Files, Staff Member Office Files, Patrick Buchanan, NPMP.

${ }^{127}$ U.S. Congress, Joint Economic Committee, Subcommittee on Fiscal Policy, Problems in the Administration of Public Welfare: Hearings, Part 2, 92 Cong., 2nd sess., May 4, 1972, 599.

${ }^{128}$ Subcommittee on Fiscal Policy, Problems in the Administration of Public Welfare: Hearings, Part 1, 211.

${ }^{129}$ Tillmon, "Welfare Is a Women's Issue," 111.

${ }^{130}$ Qtd. in U.S. Congress, Senate, Committee on Finance, Social Services Amendments of 1974: Report, 93rd cong., 2nd sess., Dec. 14, 1974, 43-4.

${ }^{131}$ Congressional Record, 93 Cong., 2nd sess., Dec. 4, 1974, 38197-8.
} 
position drew support from some middle-class feminist organizations. Witnesses for the National Organization for Women, for example, testified that the "climate in divorce and enforcement," far from allowing "women [to] make money on divorce," actually forced many middle-class women to go back to "living with their parents" or go on welfare because their ex- husbands had refused to pay court-ordered child support or alimony payments. ${ }^{132}$ Justified by lawmakers as necessary to protect taxpayers from footing the bill for "bad behavior," and taken up by middle-class women's advocates, child support enforcement and paternity establishment requirements jeopardized poor women's rights at the same time as they extended the umbrella of state protection to both middle-class women and to taxpayers.

Requirements that all welfare mothers identify the fathers of their nonmarital children, cooperate in securing court-ordered child support payments, and assign their support rights to the state imposed a diminished civic status on poor women and created distinctions among women based on marital status and economic resources. Where women who did not have to depend on AFDC could choose to use new public resources to secure support payments, welfare mothers were required to do so or risk losing their only means of economic support. As Natalie Heineman of the Child Welfare League of America testified, the new law would require that "paternity must be established for AFDC children born out of wedlock" but other "children born out of wedlock ... need not have their paternity established unless their mother considers it to be in her, or the child's best interest." ${ }^{33}$ A spokeswoman for the League of Women Voters put the matter even more bluntly. The proposals before the Congress “... would segregate public assistance recipients in families with dependent children from other separated families" and "isolate them further" from the "mainstream of American life." 134

Like many state and local eligibility criteria, paternity establishment procedures may have been intended to dissuade otherwise eligible women from applying for assistance. ${ }^{135}$ According to a 1964 report by the New York Commissioner of Welfare, the savings that accrued from aggressive support enforcement came to the "states not from relatives' contributions, but by discouraging eligible applicants from applying altogether." ${ }^{136}$ The goal of federally enforced child support, the League of Women Voters noted, was similar: to achieve "reduction in the numbers of families with children on welfare rolls." ${ }^{137}$ By positioning welfare recipients and the fathers of their nonmarital children as welfare "cheats" whose participation in the support of the family had to be coerced, these laws effectively suppressed "poor women's voices" and invalidated their "claims on the state." ${ }^{138}$ Indeed, child support enforcement and paternity establishment laws grew from the assumption that the welfare poor had already forfeited basic rights by virtue of their poverty. The point was not to provide for poor children; it was to reduce costs. As one mid-1960s report concluded, paternity establishment and child support enforcement proceedings made it clear that the "only reason the Court listens to [poor women] ... at all is for the sake of the taxpayer." 139

\footnotetext{
${ }^{132}$ Testimony of Elizabeth Spalding and Betty Berry, U.S. Congress, Senate, Committee on Finance, Child Support and the Work Bonus: Hearings, 93rd cong., 1st sess., Sept. 25, 1973, 176-7, 201.

${ }^{133}$ Testimony of Natalie Heineman, U.S. Congress, Senate, Committee on Finance, Child Support and the Work Bonus: Hearings, 93rd cong., 1st sess., Sept. 25, 1973, 120.

${ }^{134}$ Testimony of Martha S. Greenawalt, U.S. Congress, Senate, Committee on Finance, Child Support and the Work Bonus: Hearings, 93rd cong., 1st sess., Sept. 25, 1973, 214.

${ }^{135}$ For a detailed analysis of how bureaucratic processes and the imposition of "administrative burdens" have been used to achieve policy ends difficult to achieve through legislation in such areas as voting rights, abortion access, and welfare services, see Pamela Herd and Donald Moynihan, Administrative Burden: Policymaking by Other Means (New York, 2019).

${ }^{136}$ Robert Veit Sherwin, “The Law and Sexual Relationships,” Journal of Social Issues 22, no. 2 (Apr. 1966): 109122, here 114. See also Solinger, Wake Up Little Susie.

${ }^{137}$ Greenawalt, Committee on Finance, Child Support and the Work Bonus: Hearings, 213.

${ }^{138}$ Kohler-Hausmann, Getting Tough, 164.

${ }^{139}$ Sherwin, "The Law and Sexual Relationships," 114.
} 
Policing the welfare rolls on behalf of the taxpayer drew a line between tax-eater and taxpayer where one did not exist. As a group of welfare activists pointed out in the early 1970s, "everybody-well almost everybody-in this country is on welfare." ${ }^{140}$ Sometimes such assistance was direct, as in the case of Social Security or Medicare. Other times it was indirect, done through regulation or through the tax code, as in the case of the minimum wage or the Home Mortgage Interest Deduction. ${ }^{141}$ At the same time, as one welfare mother reminded the Senate Finance Committee, welfare recipients did, in fact, pay state and local sales taxes, not to mention imputed property taxes through rent payments. This insight that welfare recipients were taxpayers deserving of protection was central to the NWRO's organizing strategy. Nevada activist Mary Wesley recalled,

"When I heard [NWRO founder] George Wiley talk about welfare, that's what made me know not to feel ashamed": He said it was taxpayers' money. Now my father had died when I was three. He worked and his money was put into taxes, and he never drew anything out of it. All of my friends and relatives who had worked had taxes taken out of their checks, whether they wanted it or not. Then I didn't feel ashamed no more. ${ }^{142}$

In a testament to the power of a political discourse that defined taxpayers against tax-eaters, however, other welfare recipients rehearsed the demeaning cultural scripts that undermined their own claims to full citizenship. One AFDC recipient told a reporter for the Baltimore Sun, for example, "I feel a poor person should work as much as another." Said another welfare recipient, "I don't like having to sit back and wait on other people's tax, when I can be out working." 143 These confessions reflect the erasure of the work done by poor women inside the home and of their contributions as taxpayers.

From 1967, national policy, reinforced by political and popular discourses, effectively defined and stigmatized welfare recipients as criminals who had forfeited their claims on the state. This process of identifying and marginalizing "tax-eaters" in turn defined and empowered taxpayers as "respectable, productive citizens." ${ }^{144}$ Efforts to uncover the "huge, disguised welfare system" that "benefits the rich, and not the poor" failed to "unite low and middle income Americans around common economic interests" because both the middle class welfare state and the taxes paid by the poor and near poor were relatively difficult to see. ${ }^{145}$ The former was often mediated through intermediary institutions or defended as a kind of earned "annuity," and the latter were collected in small increments or levied indirectly in the form of higher rents or prices. ${ }^{146}$ The visibility of both AFDC and the federal income tax, set against the backdrop of economic transformation and decline, undermined the power of a progressive tax politics to underwrite a new political consensus. This was neither natural nor inevitable, but rather the product of deliberate political choices. As the NWRO's Alice Nixon pointed out in 1967, lawmakers had used welfare

\footnotetext{
140“The Real Welfare Crisis," in Welfare Mothers Speak Out: We Ain't Gonna Shuffle Anymore, eds. Thomas Howard Tarantino and Reverend Dismas Becker (New York, 1972), 17-24, here 17.

${ }^{141}$ For more on the "hidden welfare state," see Christopher Howard, The Welfare State Nobody Knows: Debunking Myths About U.S. Social Policy (Princeton, NJ, 2007). For more on the political implications of this "submerged state," see Suzanne Mettler, The Submerged State: How Invisible Government Policies Undermine American Democracy (Chicago, 2011). See also Brian Balogh, The Associational State: American Governance in the Twentieth Century (Philadelphia, 2018).

${ }^{142}$ Mary Wesley, qtd. in Orleck, Storming Caesars Palace, 145-6.

${ }^{143}$ Qtd. in James Dilts, "Welfare," Baltimore Sun Magazine, Mar. 2, 1969, folder: Shapiro v. Thompson, box 407, HBP.

${ }^{144}$ Kohler-Hausmann, Getting Tough, 122.

145“The Real Welfare Crisis," 17; Movement for Economic Justice, Flier: “The Tax Justice Project: Tax Aid, Tax Education, Tax Action," undated, folder: 8, “TJP Mailings: Flyers Newsletters," box 22, Wisconsin Historical Society (WHS).

${ }^{146}$ On the failure of progressive tax politics in the 1970s, see Michelmore, "What Have You Done for Me Lately?"
} 
recipients, "black and poor white," as "economic footballs." But, of course, lawmakers had little interest in "changing the image of the welfare recipients." It was too useful. ${ }^{147}$

In the late 1960s, Congress began to reconfigure the U.S. welfare state and with it the relationship between governed and government. Congressional conservatives in both parties led the charge, but welfare reform depended on both a liberal reform politics that had long encouraged the majority of Americans to see themselves as taxpaying citizens with legitimate claims on the state and an emergent feminism that prioritized equality in the labor market over the recognition and compensation of the domestic labor traditionally done by women. Over the next decades, lawmakers at the local, state, and national levels honed the policy tools first introduced in the Social Security Amendments of 1967: workfare, child support enforcement, and policies designed to punish out-of-wedlock childbearing and encourage heterosexual marriage. Sold as necessary to relieve taxpayers from "unnecessary burdens," these policy and political choices effectively criminalized poor women's productive and reproductive choices and paved the way for the "end [of] welfare as we know it" in 1996. That year, the Personal Responsibility and Work Reconciliation Act-better known simply as Welfare Reform-codified the reorientation of welfare policy that had begun three decades earlier. The new law transformed the goals of the welfare program. Rather than reducing poverty, the 1996 law charged states with simply reducing "welfare rolls" by "promoting work, marriage, and two parent families."148 Complementary antipoverty policies, including the Earned Income Tax Credit and the Childcare Tax Credit, reinforced not only the workfare state-both are available only to those with some amount of earned income-but also the privileged position of taxpayers in the late twentieth and early twenty-first centuries. ${ }^{149}$

This reconfiguration of the rights and obligations of citizenship was not simply retrenchment, nor was it an uncomplicated effort to roll back the state. Indeed, throughout this period the federal government not only took on new powers to regulate the behaviors of poor women and men-through such policy instruments as child support enforcement, workfare, and "family caps," but it also it promised to protect the rights and material interests of taxpayers. The 1967 law laid the groundwork for what Gwendolyn Mink has called the "welfare police state" by defining the productive and reproductive behaviors of the welfare poor as a kind of criminal fraud perpetrated against taxpayers. In recent years, even traditionally popular antipoverty programs, including Medicaid and the Supplemental Nutrition Assistance Program (SNAP), have been attacked as taxing the "makers" to reward the "takers." Proposals to introduce work requirements into other parts of the already tattered social safety net sound remarkably like decades-old defenses of WIN. Former Kentucky Governor Matt Bevin, for example, defended a proposal to add work requirements to the state's Medicaid program by suggesting that Medicaid recipients could and should work. "Why," he asked PBS's Judy Woodruff, "should somebody have to go to work every day and pay taxes to provide something to someone who could do the same thing but chooses not to?" 150

\footnotetext{
${ }^{147}$ Committee on Finance, Social Security Amendments of 1967: Hearings (Part II), Sept. 19, 1967, 1467.

${ }^{148}$ Qtd. in Smith, Welfare Reform and Sexual Regulation, 94.

${ }^{149}$ For a cross-national analysis of the histories of the EITC and the CTC, see Joshua T. McCabe, The Fiscalization of Social Policy: How Taxpayers Trumped Children in the Fight Against Child Poverty (New York, 2018).

${ }^{150}$ Judy Woodruff interview with Gov. Matt Bevin, News Hour, Public Broadcasting Systems, Jan. 15, 2018, https://www.youtube.com/watch?v=9oZ3BfDe4_Y (accessed Mar. 31, 2021). Bevin's proposal came after Seema Verma, the head of the Trump administration's Centers for Medicare and Medicaid Services (CMS), announced that CMS would allow states to attach work requirements to their Medicaid programs. According to Verma, requiring Medicaid recipients to work would enable poor "families and individuals to attain or retain capability for independence and self-care." In the wake of Verma's announcement-which reversed the position taken by the CMS during President Barack Obama's tenure in office-states hurried to submit plans to require Medicaid recipients to work. If these changes survive court challenges, Medicaid may join other "social safety net" programs that
} 
The 1967 law reframed the meaning and purpose of "welfare reform" and the value of women's family and market labor in significant and lasting ways. By requiring women-even women with young children-both to work for wages and to help the state in securing child support payments, the law clearly privileged the rights and interests of taxpayers above those of poor families. The policy channels carved in 1967, as well as the discursive frameworks deployed to justify them, in turn played critical roles in the "production of knowledge about inequality, deviance, and different categories of Americans."151 Empowered by political discourse and attention, and increasingly organized at the grassroots-itself both evidence of a shared political consciousness and an engine that produced such an identity-taxpayers insisted that their claims on the state be recognized and met. While the "right turn" of the late twentieth century is often called "anti-statist," at stake was not the elimination of state protection and services, but the redirection of that protection and those services toward, and for, favored groups. Welfare policy and politics played a key role in sorting out who was entitled to favored treatment by the state. ${ }^{152}$

Molly C. Michelmore is a professor of history at W\&L University, USA. Her research focuses on the development of the U.S. tax system and its political and social implications. Her first book, Tax and Spend: Tax Politics, the Welfare State and the Limits of American Liberalism, was published by the University of Pennsylvania Press in 2012. Her current research examines how various groups have used their political and legal identities as taxpayers to effect policy changes.

condition eligibility on recipients' willingness or ability to perform market labor. For more, see Seema Verma, qtd. in Lola Fadulu, "Why States Want Certain Americans to Work for Medicaid," The Atlantic, Apr. 12, 2019, https:/ www.theatlantic.com/health/archive/2019/04/medicaid-work-requirements-seema-verma-cms/587026/ (accessed Mar. 31, 2021).

${ }^{151}$ Kohler-Hausmann, Getting Tough, 12.

${ }^{152}$ For more on how this played out at the state level, see Isaac William Martin, The Permanent Tax Revolt: How the Property Tax Transformed American Politics (Stanford, CA, 2008). On how "logics of legitimacy" shape policy outcomes, see McCabe, The Fiscalization of Social Policy. 